\title{
The Impact of Using Electronic Media in English Teaching for Elementary and Secondary Students in Thailand
}

\author{
Unchana Klentien and Weeranan Kamnungwut
}

\begin{abstract}
The main objective of this research is to examine the impact of using electronic media software program in teaching English for students in $\mathbf{1 0 0}$ elementary and secondary schools under the Office of Basic Education Commission (OBEC). This software program was designed to help students memorize vocabulary more effectively and allow them to form a sentence in their mind more easily and quickly. The findings showed that a high score of frequency of program use or a so-called 'diligence score' was correlated with the length of time students had spent on the program and the number of vocabulary and sentences students had learned from the program, while a high score of proficiency or a so-called 'proficiency score' was correlated with the number of vocabulary students had learned, points from the lessons' tests and exercises, and the level of lessons they had gone through. In addition, the students were greatly satisfied with the program in all aspects, ranging from learning activities in the lessons and website, contents, and teaching techniques, respectively.
\end{abstract}

Index Terms-Electronic media, English teaching, learning, English software program.

\section{INTRODUCTION}

English teaching in Thailand nowadays is using a variety of techniques. A number of media technologies are used as a tool to encourage students to learn English for effective communication. English teaching and learning must not limit only in classroom but teachers have to support students' learning with a good teaching system and create environment that allows students to practice their language skills upon their levels. In order to achieve effective language teaching, students must have an opportunity to practice the language skills as much as possible, both in and outside classroom; the teaching process must be consistent with the nature and characteristics of the language; learning and teaching activities should be varied and comprised of various activities for enhancing language skill practice, training students abouthow to study language on their own to create self-reliant learners (learner independence) and contributing to a lifelong learning by using foreign language as a tool for further education and occupational purpose, which is a key component of a learning reform [1].

Learning English via the internet network is one way to increase effectiveness of English learning of students. Students can practice language by choosing topics and levels of lessons from a wide variety of activities based on their interests and skill levels. Language learning from electronic media on the internet is the utilization of materials and

Manuscript received March 12, 2014; revised May 22, 2014.

U. Klentien and W. Kamnungwut are with Srinakharinwirot University, Bangkok, Thailand (e-mail: unapor@gmail.com, raetae7@hotmail.com). resources available online as a medium to gain knowledge for effective teaching and development of learners. Electronic lessons usually have selective contents, learning activities, exercises, and tests and allow students to revise them at any time. Students will also be encouraged to respond to the contents of the lessons. Also, electronic lessons can link to many other learning resources of the related subjects. This learning technique provides students with interesting lessons that make study more fun, and thus help to develop the students' knowledge and skills efficiently [2].

Additionally, Singhal [3] argued that teaching language via the internet can help the learners to understand language in a real social and cultural context, with practical and up-to-date information. Moreover, while searching information from the internet, students will be able to improve their English reading skill; this is consistent with the teaching and learning technique that fosters self-reliant learning or learner independence and lifelong learning. This open-ended learning style can reduce restrictions and make the teaching more flexible and appropriate for a larger group of students. Furthermore, it provides an opportunity for the learners to get to novel sources of learning that meet their individual needs. This educational approach potentially reduces barriers to access to traditional learning and encourages students to learn at their own pace anywhere and anytime [4].

Thus, the Office of the Basic Education Commission (Ministry of Education) has adopted an English teaching technique using electronic media software program in English education for the youth and students in Thailand, as one of the preparations for the upcoming ASEAN Community. For this reason, the researchers are interested in using electronic media in English teaching in order to improve students' vocabulary and grammar and enhance students' motivation for further study.

\section{RESEARCH APPROACH AND METHODOLOGY}

\section{A. Research Question and Objectives}

The objective of this research is to find out whether the students in 100 schools under the Office of the Basic Education Commission that teach English by using the electronic media have the diligence score and English proficiency score in the same direction and to what extent the students' satisfaction with the program is. Therefore, the researchers studied the effects of using electronic media in teaching English to students in 100 schools under the Office of the Basic Education Commission to determine the relationship between the degree of diligence and the English 
proficiency of the students and the students' satisfaction in using English with electronic media.

\section{B. Sample and Participants}

The population of this study isstudents in grade 4-6 of elementary schools and grade 1-3 of secondary schools under the Office of the Basic Education Commission, Ministry of Education, who are studying in the academic year of 2013. The condition is such schools must have computers and audio-visual equipment available. Not being able to study the whole population due to a constraint of budget, the researchers used a simple random sampling method to choose the sample group that met previously mentioned condition, in accordance with the budget received. A hundred schools from across the country were chosen, with 40 student participants each, resulting in a total sample group of 4,000 students.

\section{Ethical Issues}

Information and identity of the learners surveyed in this research were not revealed and used only for research and statistical purposes.

\section{Research Instruments}
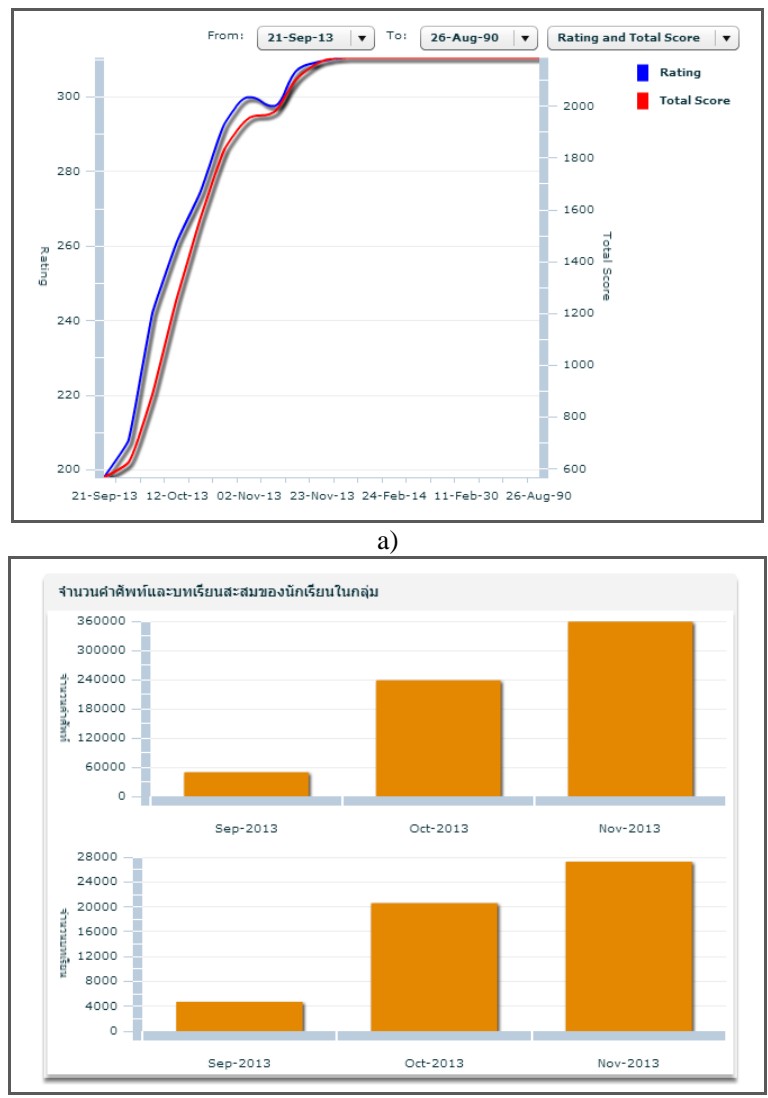

b)

Fig. 1. Graph samples: An overview of the use of electronic media software program in teaching English for students in 100 schools under the office of the basic education commission.

The instruments used in the experiment and data collection were English teaching electronic media and a questionnaire. 1) The English teaching electronic media was designed to use with multimedia computers; the program consists of training lessons for English language skills e.g. reading, listening, speaking, writing, vocabulary, and grammar. In the lesson of word meaning, sentence samples were deliberately chosen to help the students understand how to apply the terminology in a real situation. The student's performance will be shown on the computer screen so each student can track his or her own progress in learning. The student's performance will also be concluded at the end of each lesson, together with a brief overview of all lessons the student has gone through. In addition, the program will keep record of a student's points and learning results for each student to select or revise the learning lessons that best suit their needs. Regarding a speaking lesson, the program can record a learner's voice via microphone and compare it in a form of graphs showing the frequency of the sound (wave form) with respect to the native sound in the program. The data about learning results, levels of lessons, and detailed list of vocabulary and grammar rules the students have learned kept by the program were used in this research to find their correlation. 2) The questionnaire was used to assess satisfaction of the students after using electronic media for learning English, based on the Liquor Mart's 5-point Likert scale (see Fig. 1-Fig. 5).

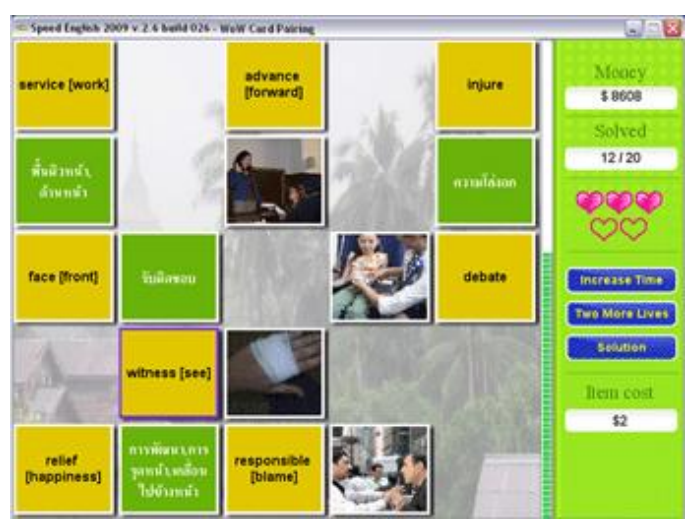

Fig. 2. Lesson sample: word-image pairing.

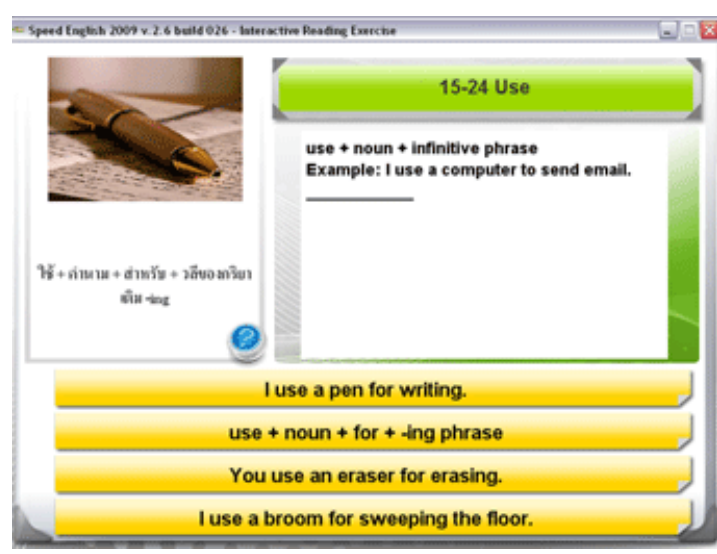

Fig. 3. Lesson sample: interactive reading

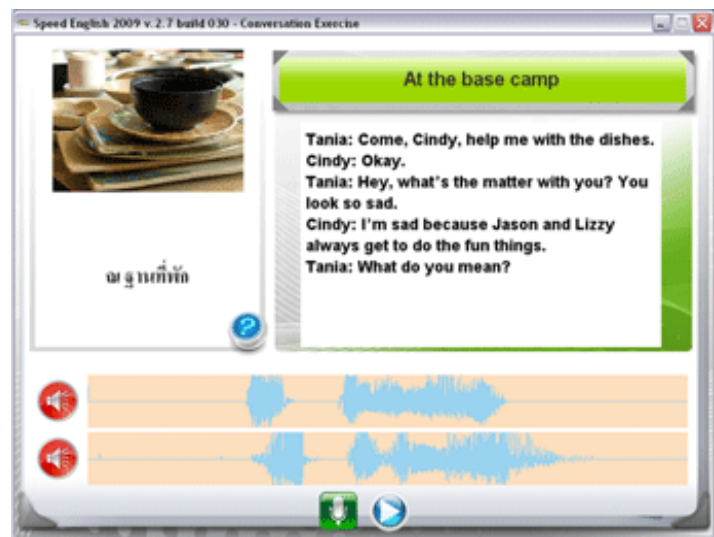

Fig. 4. Lesson sample: conversation. 


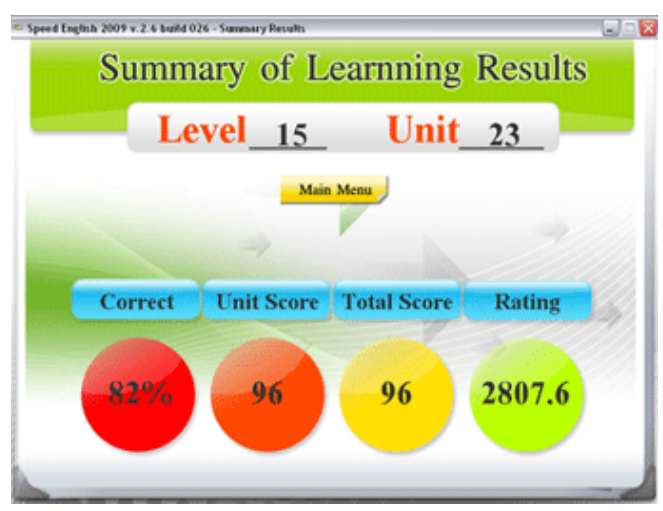

Fig. 5. Summary of learning results.

\section{FINDINGS AND ANALYSIS}

The experiment was conducted in the second semester of the academic year of 2013 with a period of one month for data collection. The students were asked to do a test to assess their level of English and then asked to use the English teaching electronic media programfor one month. Thepoints the students got from the learning were collected to compare their diligence score and proficiency score. The results were as follows:

- The relationship between the level of diligence and English proficiency of the students in the schools under the Office of the Basic Education Commission who usedthe electronic media in English class.

\section{A. Pearson Correlation}

From Table I, for the relationship between the point output (diligence) and the variables used in the analysis of the students in the schools under the Office of the Basic Education Commission, the P-value was equal to $.000, .000, .000, .000, .000, .000, .000, .000, .000$, . $000, .000$, and .000 , which was less than .05 , consistent with the results of the variables used in the analysis. In conclusion, the point output (diligence) and the ability output were correlated in a direct variation at the statistical significance of .05 , which means students with higher point level (diligence) had better English proficiency as well.

TABLE I: THE CORRELATION BETWEEN THE POINT (DILIGENCE) AND THE ABILITY OUTPUT AND THE VARIABLES USED IN THE ANALYSIS

\begin{tabular}{|c|c|c|c|c|}
\hline \multirow{3}{*}{ Analyzed Variable } & \multicolumn{4}{|c|}{ Outputs } \\
\hline & \multicolumn{2}{|c|}{ Point } & \multicolumn{2}{|c|}{ Ability } \\
\hline & $r$ & $p$-value & $r$ & $p$-value \\
\hline Archived Lesson & $.457 * *$ & .000 & $.233^{* * *}$ & .000 \\
\hline Finished Lesson & $.899 * *$ & .000 & $.479 * *$ & .000 \\
\hline Point(diligence) & - & - & $535 * *$ & 000. \\
\hline Ability & $* * 535$ & 000. & - & - \\
\hline Level & $* * 259$. & 000. & **909. & 000. \\
\hline Unit & $* * 492$. & 000. & $* * 291$. & 000. \\
\hline $\begin{array}{l}\text { Average Vocabulary per } \\
\text { hour } \\
\text { Total time of }\end{array}$ & **296. & 000. & $* * 135$. & 000. \\
\hline learning(minute) & $* * 794$. & 000. & $* * 417$ & 000 . \\
\hline Known Vocabulary & $* * 883$. & 000. & $* * 667$. & 000. \\
\hline Studied Vocabulary & $.843 * *$ & .000 & $.338 * *$ & .000 \\
\hline Studied Contexts & $.901 * *$ & .000 & $.457 * *$ & .000 \\
\hline Studied Sentences & $.908 * *$ & .000 & $.490 * *$ & .000 \\
\hline Studied Word & $.896 * *$ & .000 & $.537 * *$ & .000 \\
\hline
\end{tabular}

** The statistical significance was .05.

\section{B. Multiple Regression Analysis}

From Table II, when analyzing the pointoutput (diligence) of the students in schools under the Office of the Basic Education Commission who used the English electronic media, it was found that the level of overall point had direct variation with the total time of learning (minute) $\left(b_{1}\right)$ the number of known vocabulary $\left(b_{2}\right)$, and the number of studied sentences $\left(b_{3}\right)$, with regression coefficients of 1.535, 3.339, and 4.194, respectively, and at the statistical significance of .01.

TABLE II: THE RELATIONSHIP BETWEEN POINT OUTPUT (DILIGENCE) AND VARIABLES USED IN THE ANALYSIS

\begin{tabular}{|c|c|c|c|c|}
\hline The Linear regression parameters & $\begin{array}{c}\text { Unstandardized } \\
\text { (B) }\end{array}$ & $\begin{array}{l}\text { Standardized } \\
(\beta)\end{array}$ & $\begin{array}{c}\text { Statistic } \\
t\end{array}$ & $\begin{array}{c}\text { Prob. } \\
(p)\end{array}$ \\
\hline (Constant) & 1.908 & & .057 & .954 \\
\hline Total Time of Learning( minute) $\left(b_{1}\right)$ & 1.535 & .291 & $25.330 * *$ & .000 \\
\hline Known Vocabulary $\left(b_{2}\right)$ & 3.339 & .267 & $14.521 * *$ & .000 \\
\hline Studied Sentence $\left(\mathrm{b}_{3}\right)$ & 4.194 & .472 & $25.354 * *$ & .000 \\
\hline Adjusted R Square & & & & \\
\hline Std. Error of the Estimate & & & & \\
\hline $\mathrm{F}$ & & & & \\
\hline Sig & & & & \\
\hline
\end{tabular}

** The statistical significance was .01

TABLE III: THE RELATIONSHIP BETWEEN THE ABILITY LEVEL OF STUDENTS AND VARIABLES USED IN THE ANALYSIS

\begin{tabular}{|c|c|c|c|c|}
\hline $\begin{array}{c}\text { The Linear regression } \\
\text { parameters }\end{array}$ & $\begin{array}{l}\text { Unstandardized } \\
\text { (B) }\end{array}$ & $\begin{array}{l}\text { Standardized } \\
(\beta)\end{array}$ & $\begin{array}{c}\text { Statistic } \\
t\end{array}$ & $\begin{array}{c}\text { Prob. } \\
(p)\end{array}$ \\
\hline (Constant) & -118.015 & & $27.644 * *$ & .000 \\
\hline Known vocabulary $\left(b_{1}\right)$ & .157 & .098 & $5.751 * *$ & .000 \\
\hline Point $\left(b_{2}\right)$ & .031 & .240 & $15.296^{* *}$ & .000 \\
\hline Level $\left(b_{3}\right)$ & 167.716 & .803 & $97.232 * *$ & .000 \\
\hline Adjusted R Square & & & & \\
\hline Std. Error of the Estimate & & & & \\
\hline $\mathrm{F}$ & & & & \\
\hline Sig & & & & \\
\hline
\end{tabular}

From Table III, when analyzing the ability level of the students in schools under the Office of the Basic Education Commission who used the English electronic media, it was found that the level of overall proficiency had direct variation with the number of known vocabulary $\left(b_{1}\right)$, rating $\left(b_{2}\right)$, and level $\left(b_{3}\right)$, with regression coefficients 
of $.157, .031$, and 167.716 , respectively, and at the statistical significance of .01 .

- The satisfaction of the students in the schools under the Office of the Basic Education Commission towards the use of the electronic media in English class.

From Table IV, the satisfaction of the students in the schools under the Office of the Basic Education Commission towards the use of the electronic media in English class was in a high level. It was also found that the students had high satisfaction with all aspects of the program, ranking by points from learning activities and website, presentation, and innovative teaching, respectively.

TABLE IV: THE SATISFACTION OF THE STUDENTS TOWARDS THE USE OF THE ELECTRONICS MEDIA IN THE ENGLISH CLASS

\begin{tabular}{|c|c|c|c|}
\hline Satisfaction & $\begin{array}{l}\text { Average } \\
(n=400)\end{array}$ & S.D. & $\begin{array}{c}\text { Satisfaction } \\
\text { Level }\end{array}$ \\
\hline Instruction & 4.35 & 0.72 & High \\
\hline 1.Total time used in the whole lesson & 4.13 & 0.57 & High \\
\hline 2. Duration of each learning activity & 4.28 & 0.79 & High \\
\hline $\begin{array}{l}\text { 3. Proper application of technology in } \\
\text { learning }\end{array}$ & 4.15 & 0.74 & High \\
\hline 4. Self-learning condition & 4.50 & 0.52 & High \\
\hline 5. All time access & 4.30 & 1.09 & High \\
\hline 6. All time revision & 4.75 & 0.62 & Highest \\
\hline Presentation & 4.45 & 0.67 & High \\
\hline 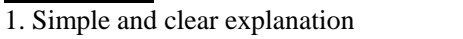 & 4.42 & 0.52 & High \\
\hline 2.Step-by-step presentation & 4.92 & 0.41 & Highest \\
\hline 3. Proper amount of topics in each & & 1.14 & High \\
\hline lesson & 3.75 & & \\
\hline 4. Interesting presentation & 4.67 & 0.38 & Highest \\
\hline 5. Proper test and instant assessment & 4.50 & 0.88 & High \\
\hline Learning Activities and Website & 4.31 & 0.68 & High \\
\hline .1 Overall interesting rate of lesson & 4.33 & 0.45 & High \\
\hline 2. Learning multimedia & 3.68 & 0.98 & High \\
\hline 3. Instant learning access & 4.42 & 0.52 & High \\
\hline 4. Simple and clear topic & 4.58 & 0.72 & Highest \\
\hline 5. Instant, simple, and clear output & 4.75 & 0.45 & Highest \\
\hline 6. Compact presentation & 3.75 & 0.87 & High \\
\hline 7. Proper alphabet and picture & 4.50 & 0.52 & High \\
\hline 8. Proper graphic design & 4.83 & 0.39 & Highest \\
\hline Total & 4.37 & 0.69 & High \\
\hline
\end{tabular}

\section{DISCUSSIONS AND CONCLUSIONS}

It can be concluded from the research study that the variables correlated with high diligence score of the students were long time spent in learning English from the electronic media, an increase in the number of known vocabulary, and an increase in the number of studied sentences, while the variables correlated with high proficiency score of the students were an increase in the number of known vocabulary, higher points from the lessons, and higher level of English learning. Diligence can lead to high scores of the other three variables because it is a key factor to the pursuit of knowledge and self-learning. If students can overcome their own mind in pursuing knowledge, success will occur since self-learning is a result of willingness (voluntary learning) and curiosity not obligation. Moreover, since the students are voluntary to learn, they can by self-resourceful by knowing what they want to learn, what skills and information they need, and how to acquire those skills and information. Self-learning, therefore, is vital. When students have higher English proficiency in the skills of listening, speaking, reading or writing, their English learning potential will increase in a positive way. Furthermore, learners should be encouraged to feel confident in communicating in English with teachers while teachers should design and prepare proper activities that are similar to real-life situations for students to practice e.g. simulations, role-playing, and group discussion. Integration of listening, speaking, reading and writing skills in learning activities will reinforce learners' attention. Speaking of learners' attention, students' diligence level will increase with interesting learning techniques for they will make learning much more enjoyable than ordinary textbooks [5]-[10].

In terms of satisfaction towards the electronic media English lessons, students and teachers were highly satisfied with the lessons because they enabled students and teachers to learn and exchange ideas more often online, comparing to in-class lessons in which students might not be socially assertive. Also, the electronic lessons were more interesting since they had adopted and mixed various techniques of presentation, including text, audio, pictures, graphics, charts, graphs, animations, and even video home system(VHS) to deliver contents in the closet pattern to real teaching in classroom. Computer assisted instruction (CAI) could attract the attention of students and motivate them to learn by themselves, even those with a physical handicap. Electronic lessons can also respond to the needs of learners and increase their satisfaction towards the learning. Therefore, the teaching of English should focus on providing students with the ability to communicate better and be confident in their own communication styles. Learning activities should be well-planned and well-designed to be as close as possible to real communication situations in business via various scenarios, role-playing, and group discussions, with the integration of listening, speaking, reading, and writing skills to make the most realistic activities.

\section{RECOMMENDATIONS FOR LECTURERS TO CREATE ELECTRONIC LESSONS}

Learning subjects that require memorization or have same teaching pattern always cause boredom to students. Therefore, teachers must provide instructional materials to stimulate and increase the students' satisfaction in learning. Electronic media can be used to alleviate the burden of teachers as a supplementary course by applying the learning contents with activities or game for students' enjoyment. Most importantly, electronic media and teaching material will help students to broaden their concepts of knowledge from just textbooks. It will also help satisfy students with what there are learning and help them to understand the lessons better.

\section{ACKNOWLEDGMENT}

The research of 'The Impact of Using Electronic Media in English Teaching for Elementary and Secondary Students in Thailand' was funded under a research project of the Office of The Basic Education Commission (Thailand), for the budget year of 2013. This research was complete with high assistance of many individuals. The authors would like to thank and express the gratitude to every individual who has made this project a great success. 


\section{REFERENCES}

[1] Department of Curriculum and Instruction Development, Ministry of Education, Management of Foreign Language Learning Group According to Fundamental Education CurriculumB.E. 2544, Bangkok: Printing house of the Express Transportation Organization of Thailand, 2003.

[2] N. Oracha, Construction of Web-Based Thai Language Titling Using Correct Words for MathayomSuksa 3 Students, Chiang Mai: Chiang Mai University, 2008.

[3] B. Thuwanon, Development of Web-Based Electronic Media Supporting Teaching and. Learning of English in Grade Range 3, Master of Arts (Education-Teaching), The Graduate School Kasetsart University, 2006.

[4] K. Jintawee, Research on Proper Patterns of Websites and Electronic Lessons for E-Learning in Undergraduate School, Office of the Higher Education Commission, Ministry of Education, 2010.

[5] P. R. Harris, High Performance Leadership: Strategies for Maximum Career Productivity, Illinois: Scoot, Foresman, 1996.

[6] P. J. M. Groot, "Computer assisted second language vocabulary acquisition," Language Learning \& Technology, vol. 4, no. 1, May 2000, pp. 60-81.

[7] A. C. Pajtek, Computer-based Versus Paper-based Instruction: Effectiveness and Motivation, Michigan State University, Department of Linguistics and Germanic, Slavic, Asian and African Languages, 2002.

[8] R. F.Wang, "Action, verbal response and spatial reasoning," Department of Psychology and Beckman Institute, University of Illinois, 2004.

[9] S. A. Sultana and M. A. Kamal, Distance Education and Open Learning in a Developing Country like Bangladesh: Philosophy and Reality, 2005.
[10] R. E. H. Hassan, "Software Application for Computer Aided Vocabulary Learning in a Blended Learning Environment," Thesis. M.A. Teaching Arabic as a Foreign Language, Arabic Language Institute, the American University in Cairo, 2010.

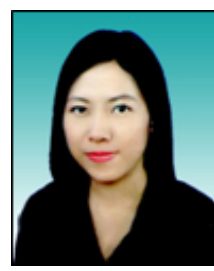

Unchana Klentien was born in Bangkok, Thailand in 1985, and currently she is a lecturer in computer for communication at the College of Social Communication Innovation, Srinakharinwirot University, and she is also working as the deputy director for the Center for Academic Services, Srinakharinwirot University. She received her bachelor degree in educational technology with a first-class honor from Silpakorn University, and master degree in audio-visual communications with distinct from Chulalongkorn University, and she is currently doing her PhD in computer education at King Mongkut's University of Technology North Bangkok.

Her research interests are educational technology, curriculum development for both online and offline, and learning organization.

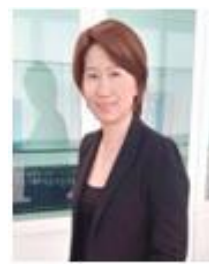

Weeranan Kamnungwut was born in Bangkok, Thailand in 1974, and she is a lecturer in cyber business management at the College of Social Communication Innovation, Srinakharinwirot University, and she is also the director of the Center for Academic Services at Srinakharinwirot University. She did her first degree at the Faculty of Arts, Chulalongkorn University, her master in international business at Brunel University,

$\mathrm{UK}$, and $\mathrm{PhD}$ in management at Birkbeck College, University of London, UK.

Her research interests include industrial cluster, international business, e-business management and foreign direct investment. 